\title{
Convict Labour and the Western Empires, 1415-1954
}

\section{Clare Anderson and Hamish Maxwell-Stewart}

$<<$ Map goes here. Caption to be added $>>$

\section{Introduction}

Between 1415, when the Portuguese first used convict labour in the capture of the Moroccan city of Ceuta, and 1954, when the French penal colony in Guiana closed, the European powers transported hundreds of thousands of convicts, and employed them as unfree labour in overseas colonies. Because convict transportation has either been framed historiographically within the history of crime and punishment, or viewed as part of the history of one nation or empire, there has been a general failure to understand its pan-European scale and scope. This chapter provides a first step in that direction: synthesising the existing literature, offering a starting point for the quantification of convict numbers, and suggesting that penal transportation represented not solely an instrument of punishment or criminal reform, but formed part of a continuum of unfree labour practices that underpinned overseas European expansion.

Famously, the European colonisation of the Americas from the end of the fifteenth century was a coercive process that as a result of the devastation of indigenous peoples relied on the extraction of labour from bonded migrants. The majority of these imported unfree workers were chattel slaves purchased by traders in west and central Africa, and shipped across the Atlantic and sold into enslavement. However, European labour played an important secondary role largely through the process of indenture - a form of assisted migration whereby an individual forfeited claims to wages for a number of years in return for a 
passage to an overseas colony. ${ }^{1}$ Convicts were also transported from Britain, Ireland, Portugal, France and Spain and either sold for the period of their sentence or set to work for the state. The exploitation of penal labour was relatively new to early modern Europe although a practice widespread in the classical world. While several medieval European societies retained provisions to put convicted prisoners to work, most lacked the infrastructure and resources to implement a system of systematic penal exploitation, instead resorting to execution and other inexpensive public displays of state power. The reappearance of penal labour coincided with the establishment of the centralised state and the development of Western empires. ${ }^{2}$

Penal transportation both pre-dated and outlasted Atlantic slavery. As a practice, the removal of convict labour from Britain and Ireland was modelled on indenture, although it was a more extreme process that was socially and commercially comparable to slavery. Indeed some slaving practices can be viewed as a form of transportation, especially judicial slavery where the condemned (and on occasion their relatives) became the property of the state. This was a common route into bondage in West Africa. ${ }^{3}$ It should be noted that slavery, penal transportation and indenture have complex intertwined histories. To provide but one of many examples: convict labour on plantations in the British Caribbean was replaced in the second half of the seventeenth century by slave labour, which was in turn replaced in the nineteenth century by indentured labour from South Asia and China. In short, the three processes - penal transportation, indenture (European and Asian) and enslavement — were strongly related to each other and did not exist as distinct practices. 
Although slavery is ancient, persistent and global, it is particularly associated with European colonisation of the New World. The slave trade came under increasing attack, however, because of its unsustainability in the context of the widespread resistance of the enslaved (most famously in the Revolution of 1791-1804 in the French colony of Saint-Domingue), and pressure from metropolitan abolitionists, whether on the grounds of humanitarianism or political economy. Despite this pressure the slave trade and slavery itself were abolished only gradually across the European empires. The British outlawed slave trading in 1807 and slavery in 1834 (with ex-slaves forced into supposedly transitional 'apprenticeships'); but under East India Company pressure, Parliament excluded the Indian Empire from the 1833 Emancipation Act. Slavery was not abolished in Britain's Indian Empire until 1843, and slave owning remained legal until 1862 . The picture across other empires was similarly variegated. Slavery was abolished in most French colonies in 1848 (but Madagascar not until it became a French colony in 1896), in Dutch colonies in 1863, and in Portuguese Africa in 1869. For many empires, transportation proved a more enduring means of satisfying colonies' labour needs. As will be shown, convicts were shipped outwards from the metropole to colonies, and multi-directionally between colonies — across imperial spaces — over a period of more than five centuries.

The longevity of penal transportation as a system of securing cheap labour to aid colonial expansion can be ascribed to four inter-related factors. First, convict transportation attracted remarkably little comment from either metropolitan elites or colonial interlocutors since it could be argued that, unlike slaves, convicts were the agents of their own demise. ${ }^{4}$ Thus convicts - 
especially when sentenced in the colonies — attracted relatively little metropolitan or colonial concern.

Second, convict transportation was flexible in that it provided a means of securing a cheap, controllable and easily replaceable form of labour, and convicts could be forced to go to places where free labourers would not settle. The point here is not to compare sufferings, but to note that, though they often lived and worked under remarkably similar conditions, slaves represented a financial investment, whereas convicts usually did not. As Matthew Mancini so memorably recalled, repeating an elderly businessman's description of the leasing of convict labour in the American south: One Dies, Get Another. ${ }^{5}$

Third, penal transportation delivered an effective tool for policing metropolitan and colonial populations. In this sense it might be viewed as one element of the expansion of colonial governmentality, as well as the more general shift from the private to public management of labour in the age of imperial expansion. ${ }^{6}$

Fourth, transportation was perceived as less costly than the penal alternative - the construction of new or extension of existing penitentiaries - a point that holds even though it co-existed with local incarceration and even if it was subsequently argued that transportation systems and penal colonies cost more than convict labour saved in the hire of free labour. An exploration of these processes and the connections between them provides an account of the origins, longevity and ultimate demise of convict transportation within Western empires.

\section{Defining Convict Transportation}


Any attempt to enumerate the contribution of convict labour to European overseas colonial development rests on a definition of what constitutes penal transportation. A transported worker can be seen as an individual convicted by a civil or military court and subsequently relocated to a colony to perform labour services for a period at least nominally defined by the sentence passed upon him or her. While it is sometimes assumed that the labour of transported convicts was exploited exclusively by the state, historically this was far from the case. Thus seventeenth- and eighteenth-century British and French transportation systems relied on the sale of convicts to the private sector, where they were treated as a form of indentured labour. This illustrates the way in which convict transportation is often difficult to distinguish from other forms of labour extraction. As already pointed out, many West Africans were condemned into slavery as a result of sentences imposed upon them. The only distinction between this practice and European transportation is that, in contrast to slaves, the children of convicts were born free.

Another area of potential confusion revolves around the question of what constitutes conviction. In the seventeenth and eighteenth centuries, for example, it was not uncommon for prisoners of war to be transported. Despite the lack of a formal sentence, the state treated such individuals as convicts, especially when deemed to be in a state of rebellion. Parallels appear here with the Spanish use of transportation as a tool for dealing with rebellious Apache in America or indeed the transportation of 'mutineers' from India to the Andaman Islands in 1858. This survey includes rebels as convicts where they are fed into existing transportation flows, though it excludes prisoners of war removed to various outposts of empire, but not subjected to coercive labour extraction. Thus, 26,000 
Afrikaners taken in the South African War (1899-1902) were moved to camps in St Helena, India, Ceylon and Bermuda. They were, however, not required to work, let alone work alongside other unfree migrants. ${ }^{7}$

Finally, a considerable overlap existed between transportation and military service. The Portuguese, Spanish and British deployed prisoners convicted by civil and military courts as soldiers in areas associated with high death rates. The French operated a sophisticated variant of this system whereby on release from gaol petty criminals were forced to serve as conscripts in the notorious Bataillons d'Infanterie Légère d'Afrique (BILA). While these units were not manned by serving convicts, conviction was a necessary prerequisite of service; the BILA functioned as a military equivalent of the civil bagne in Guiana, stationed in North Africa and other colonial theatres.

The question of what ordinary people thought about penal transportation adds further depth to the question of definition. Though differences between penal and other labour categories may have seemed obvious (and meaningful) to colonial officials, it is less clear that subject populations drew such distinctions. Given the preceding sketch of the multiple overlaps between unfree labour practices, this should not be surprising. In the Australian colonies, for instance, British and Irish convicts called themselves 'slaves', at least in part as a rhetorical alignment and an appeal to the anti-transportation lobby. ${ }^{8}$ In the Indian penal settlement in Mauritius, South Asian convicts used the description sipahis (soldiers), and in Singapore they used kumpane ke naukur (East India Company servants), which was also bound up with the idea of military service (naukur). ${ }^{9}$ 
The labour services that convicts performed were diverse and could encompass land clearance; infrastructural work, including the building of barracks, fortifications, roads and bridges; agriculture and cultivation of rubber, silk and salt; tin and coal mining; working as personal servants or grooms; or maritime or military service. During the initial stages of colonisation convicts were often deployed in 'frontier' zones. These covered culturally unfamiliar, uninhabited and densely forested lands, littorals and islands. In these years, in general terms convict flows coalesced with those of other migrants, notably of African slaves and European indentured labourers. From the end of the eighteenth century, however, the character of the flows changed and most convicts were sent to specially designated penal settlements and colonies. There attempts were made to isolate them from neighbouring communities, whether comprising indigenous people or migrant settlers.

These penal settlements and colonies could be remarkably socially complex. Though most convicts were put to hard labour, in some cases, suitably qualified or educated transportees became convict clerks, overseers, policeman and foremen. The overwhelming majority of convicts were men, and women tended to form a small cohort. This meant many penal settlements and colonies were significantly homosocial. Convict women were often (though not always) confined separately, and put to different kinds of domestic labour. Furthermore, convict flows were characterised by complex racial stratifications; and European, African, American, Amerindinian, Asian and Eurasian convicts could be shipped to different colonies or settlements, separated within them, and/or made subject to differential penal and work regimes. 
Five European nations made extensive use of convict transportation to assist the wider process of colonisation. The Portuguese, Spanish, British and French deployed convicts to over forty colonial destinations bordering the Atlantic, Indian and Pacific Oceans. While some Russian convicts were shipped by sea from the Black Sea port of Odessa to the island of Sakhalin in the years 1879-1905, most were moved overland to Siberia. Because of its largely terrestrial nature, we have omitted the Russian use of transportation from this account, concentrating instead on Western European movement of convicts to and between colonies linked by sea-routes. There nonetheless existed many similarities between Russian and other European transportation systems, not least the use of convicts to supply cheap labour on colonial frontiers.

Some other European polities also experimented with transportation. Dutch East India Company courts imposed sentences of transportation on colonial populations, its settlement in the Cape receiving an estimated 2,500 Asian convicts in the period to 1799; most were convicted in Batavia. ${ }^{10}$ The Habsburgs used convict labour to stabilise frontier zones, and the Prussian state sold convicts to the Russians. ${ }^{11}$ No evidence indicates, however, that transportation was used to supply convicts to German or Italian colonies or the Belgian Congo. This is probably not accidental, as the Western empires that made the heaviest use of transportation had a history of involvement in other unfree labour practices, notably slavery.

\section{The Portuguese Empire}

The Portuguese were the first European nation to use transportation as a means of populating colonial possessions. As they were also amongst the last to end the 
practice, the Portuguese state's involvement in transportation spanned 539 years. Convict soldiers and sailors were employed in the conquest of Ceuta in 1415. Thereafter convicts, or degredados, featured in the colonisation of São Tomé as well as Angola, Mozambique, Goa and Brazil. ${ }^{12}$ Degredados were also used to man fortifications and factories in West Africa, notably El Mina. ${ }^{13}$ Those colonies associated with particularly high disease rates received large numbers of degredados; this applied particularly to Portuguese possessions in subSaharan Africa. ${ }^{14}$

Once the Portuguese had established an overseas empire, minor flows of convicts between their various colonial possessions augmented the transportation from the metropole. In the late seventeenth and early eighteenth century a threeway trade in convicts, vagrants and gypsies developed between Portugal, Brazil and Angola. ${ }^{15}$ Thus, amongst convicts in Angola in the early twentieth century, one in five came from other Portuguese colonies — notably Mozambique, the Cape Verde Islands and Goa. ${ }^{16}$ Unlike other transportation systems, the labour of degredados does not appear to have been generally used on public works projects, at least not before the latter half of the nineteenth century. Convicts were, however, commonly employed as soldiers. ${ }^{17}$ In seventeenth- and eighteenth-century Angola those that did not succumb to disease often moved into the interior, where they attempted to establish themselves as petty slavers in the Luso-African controlled trade. ${ }^{18}$ Similarly in Mozambique convicts freed upon landing frequently drifted into the interior to become sertanejos or backwoodsmen. Others set themselves up as craftsmen and retailers or occupied petty administrative positions - a necessity caused by the dearth of alternative sources of European labour. ${ }^{19}$ 
About 400 of the 1000 or so colonists sent to Bahia in Brazil in 1549 were degredados. ${ }^{20}$ As with every other Portuguese colonial possession, Brazil continued to receive drafts of convicts. As well as deporting degredados to Angola, from the 1740s onwards the Brazilian colonial authorities also shipped them to the island of Fernao de Noronah. ${ }^{21}$ Transportation to Brazil ceased only when the colony gained independence in 1822 .

There is some evidence that other Portuguese settlements followed the Australian lead and set up anti-transportation movements. Penal reforms in 1852 at first limited transportation to India for less serious offenders, and then from 1869 onwards restricted the shipping of convicts to African colonies. The exile of degradados to Cape Verde and São Tomé ended in the early 1880s and to Mozambique in 1885. Angola, however, continued to receive convicts, partially because the small size of the Portuguese population fuelled concerns that the colony would fall prey to British, French, German or Belgian imperial ambitions. In 1883 a series of purpose-built institutions (depositories) were constructed for fresh imports of degradados. At the same time agricultural penal settlements were set up in the interior, although they were soon closed because of high death rates. In 1894 an alternative plan set up a series of militarised agrarian outposts staffed by convicts. These also proved failures. Despite this, and the collapse of other agricultural schemes, it took until 1932 for transportation to Angola from metropolitan Portugal to be abolished. Even then the colony continued to receive convicts from São Tomé, Cape Verde and Guinea until the complete abolition of transportation in $1954 .^{22}$ The best estimate of the number of convicts transported by the Portuguese is $100,000 .{ }^{23}$ 
The Spanish use of transportation dates to at least the first half of the sixteenth century, when Phillip II advised his viceroys that 'some men are incorrigible, inobedient, or harmful, and are to be expelled from the land and sent to Chile, the Philippines or other parts'. ${ }^{24}$ Most convicts were sent to presidios, fortified settlements established to exert military control in colonial borderlands. This practice lasted until 1911, when the convicts held in Spanish enclaves in North Africa were repatriated. ${ }^{25}$ The total number of presidios established within the Spanish Empire is difficult to calculate, but between 1524 and 1821 over 100 were constructed in northern New Spain, Alta California and Spanish Florida alone. ${ }^{26}$ Others were established in Africa, elsewhere in the Americas, Asia and Oceania. The number of convicts transported from Spain to presidios in the sixteenth and seventeenth centuries appears to have been small, most were sent to Oran, Melilla and neighbouring settlements in North Africa. They included amongst their number a grandson of Columbus, who received a ten-year sentence for trigamy in 1563.27

High death rates meant that many presidios were short of labour and frequently demanded new consignments of convicts. ${ }^{28}$ Many laboured as fortress and dockyard construction workers in the Spanish Caribbean, where they were considered to be cheaper and more expendable than slaves. ${ }^{29}$ Between 1703 and 1811 the Acordada, the most important law enforcement agency in New Spain, issued 19,410 sentences to presidios. ${ }^{30}$ Additional numbers were sent to Havana, in Cuba, and San Juan, in Puerto Rico, from metropolitan Spain. ${ }^{31}$

The Spanish presidio system in North Africa operated from the early fifteenth century to 1911 . Some presidiarios were employed constructing 
fortifications while others served in penal military units. Hard data on the number of convicts is difficult to locate, but it is clear from desertion, death and sentence completion rates that turnover was significant. Based on the available data, we estimate that 26,000 served in Oran between 1509 and 1708 and again from 1732 until the sale of the settlement to the Ottomans in 1792. On the basis of the ratio of presidiarios serving in Oran compared to the presidios of Melilla and nearby El Peñón in the years 1772-1788, it is likely that at least a further 13,000 were sent to North Africa by the close of the eighteenth century. ${ }^{32}$ In the early nineteenth century the number of troops sent to the North African presidios declined and convicts were increasingly used as soldiers, as well as in construction and as servants, watermen, policemen, bakers and gardeners. ${ }^{33}$ Newspaper reports suggest that convict strength stood at three to six thousand at any one time. We estimate that the Spanish transported at least 40,000 during the nineteenth century. About 1000 convicts also arrived in Fernando Po from the Philippines, Cuba and metropolitan Spain between 1862 and 1899.34

Table 1. Estimates of Spanish Convict Transportation Flows, 1550-1911

\begin{tabular}{llcc}
\hline Origin & Destination & Period & Est. \\
& & & Number \\
\hline Spain & Cuba and Puerto Rico & $1769-1837$ & 4,000 \\
New Spain & New World presidios & $1550-1811$ & 25,000 \\
Spain & North African & $1550-1911$ & 80,000 \\
& presidios & &
\end{tabular}


Cuba and Fernando Po

$1862-1899$

1000

Philippines

Total

$1550-1911$

110,000

The French Empire

As early as 1552 the French used convicts on colonial expeditions in the north Atlantic, although before the nineteenth century it was more common for criminals to be sentenced to galley service in Brest, Toulon and other French ports. ${ }^{35}$ On occasion, however, petty criminals were sold as engagés or indentured servants with around 600 shipped to Louisiana between 1719 and 1721. The practice ceased because of high death rates and the falling share price of the West Indies Company, although between 1721 and 1749 a further 720 were exiled to Canada for offences that included poaching, smuggling and selling untaxed salt. ${ }^{36}$ The Seven Years War cut short the transportation of convicts to New France, and there appears to have been no further attempt to ship convicts overseas until the 1790s. During the French Revolution small numbers of political prisoners (under 700) were exiled to Cayenne (French Guiana). Despite high death rates, the policy was not abandoned until the Portuguese occupied the colony in $1809 .{ }^{37}$ The reform of the penal code in 1810 formally restricted transportation to political offenders, although the lack of a suitable site meant that in practice the punishment was not used.

French courts reintroduced transportation in 1848 as a punishment for non-political offences. The first contingent of 2,200 convicts arrived in French Guiana in 1852, directed to work 'in the most painful tasks of colonization and 
all other works of public utility'. ${ }^{38}$ While penal legislation made favourable reference to the British penal colonies in Australia, the abolition of slavery within the French Empire in 1848 provided a more immediate stimulus. ${ }^{39}$ The first convicts to arrive in Cayenne were set to work clearing the Iles du Salut for cultivation and building. Shortly afterwards an agricultural establishment was set up near the mouth of the Oyapock River on the site of a former sugar plantation, with ex-slaves used as convict overseers. ${ }^{40}$ The subsequent introduction of Indian indentured workers into Guiana after 1861 added a further layer of complexity to this interconnected history of labour exploitation.

Annual death rates of eleven percent necessitated the shifting of the first settlements in Guiana to higher ground. This did little to alleviate the problem, and of the first 8,000 French bagnards transported to South America, half were dead by 1857. As in Portuguese Angola, repeated experimentation with new locations failed to solve the problem and the colonial administration was forced to conclude that Europeans were unsuitable for hard labour in the tropics. ${ }^{41}$ While colonial subjects from Algeria, Senegal and Indo-China continued to be sent to Guiana, a new European penal colony was established in New Caledonia. It operated from 1864 to 1922, although the last convict shipment arrived in 1897.42

During this period at least 22,000 prisoners landed in New Caledonia, including 5,000 political exiles of the 1871 Paris Commune. Although the annual death rates were lower than those of Guiana, at two to three percent, they remained high by the standards of the British settlement in Australia. ${ }^{43}$ Wellbehaved prisoners were put to outdoor labour on public works projects, or hired out to private individuals. In some cases land grants were provided for expirees 
in the hope of encouraging long-term settlement. Many argued, however, that penal transportation acted as a brake on free migration, and so colonists campaigned for abolition. ${ }^{44}$ At the same time, others argued that New Caledonia amounted to a tropical paradise for the convicts and called for harsher measures. Thus in 1887 metropolitan transportation to Guiana resumed for serious offenders. Following the cessation of transportation to New Caledonia in 1897, the bagne in Guiana once more became the sole terminus of French civilian transportation policy. The last prisoner was released in 1953, and estimates of transported convicts range up to 70,000 .

A system of French military transportation operated in parallel to the Guiana and New Caledonia schemes. While the French army made use of penal battalions after 1818 , they became increasingly associated with colonial service following the occupation of Algeria in 1830. Initially three Bataillons d'Infanterie Légère d'Afrique were established in 1832-1833; with two more added in 1888 . These were manned by military convicts and prisoners sentenced to between three months and three years followed by service as a conscript. After the 1848 revolution 6,000 political and civilian prisoners were also sent to the military bagne in Africa. ${ }^{45}$ The batallions laboured in construction work and colonial engagements in Algeria, Morocco and Tunisia as well as the Crimea (1854-1856), Syria (1860-1861) and Mexico (1862-1867). Over 600,000 people served in the convict forces, including during the First World War in France. Between 1832 and 1972, when the last company was disbanded in French Somalia, men served as conscripts in penal units in colonial theatres. ${ }^{46}$ 


\begin{tabular}{llcc}
\hline Origin & Destination & Period & Est. \\
& & & Number \\
\hline France & New France & $1552-1749$ & 1000 \\
France & Louisiana & $1719-1721$ & 600 \\
France & Cayenne & $1792-1809$ & 700 \\
France & Algeria & $1848-1850$ & 6,000 \\
France and colonies & Guiana & $1852-1938$ & 70,000 \\
France & New Caledonia & $1864-1897$ & 22,000 \\
\hline Total & & $1552-1938$ & 100,300 \\
\hline
\end{tabular}

The British Empire

The English state started to experiment with transportation in the early seventeenth century although only a few dozen convicts were sent overseas before 1642. Transportation spiked during the Commonwealth, although the claim that 50,000 were sent to the Caribbean and North American colonies from Ireland alone in the period 1652-1659 almost certainly represents an overestimate. ${ }^{47}$ Many of those deported from England during this period were prisoners of war, and they continued to be sent until the defeat of the second Jacobite rebellion at Culloden in 1746. Between 1648 and that date at least 4,000 rebels and captured soldiers were transported. ${ }^{48}$ Court records indicate that they were joined by around 6,000 convicts convicted in civilian courts between 1660 and 1718, and sentenced to be sold in the Americas. After that date the pace of transportation increased, with an estimated 48,000 more sent between 1718 and 
1775. ${ }^{49}$ Although the American Revolution ended transatlantic transportation from England and Scotland, shipping contractors attempted to offload a further 1,000 convicts from Ireland between 1776 and 1789.50

Thereafter the British experimented with transportation to West Africa, sending at least one thousand convict soldiers between 1766 and 1784 to forts and trading outposts. While the use of convicts as soldiers came under fire from slaving interests (concerned that the use of white servile labour undermined the racial division of labour), it was reintroduced in 1800 and continued until the disbanding of the Royal African Corps in $1826 .{ }^{51}$ Like other European strategists the British used convicted labour to supplement military strength in tropical areas - a practice that peaked during the Revolutionary and Napoleonic wars. Roger Buckley estimates that 20 percent of all British troops serving in the West Indies between 1799 and 1802 were convicts. Dedicated penal battalions were raised in 1806 and again in 1808 for services in the West Indies. ${ }^{52}$ Given the horrendous death rates that afflicted Europeans in tropical areas, the total number of convicts serving in British military units in the period 1766-1826 must have been considerable. 53

The British first sent convicts to Australia in 1787, the Botany Bay decision largely shaped by the lack of alternative transportation destinations. Race became a key consideration. Other than as part of a military detachment, it proved increasingly difficult to deploy European unfree labour in the Atlantic world. While it was possible for the British government to supply convicts to the East India Company, the Company had its own source of penal labour. From 1787 it shipped Indian convicts to Bencoolen, a short-lived British outpost on the island of Sumatra (in the East Indies), and from 1790 to the newly conquered 
island of Penang. By the early nineteenth century it had become Company policy to send Europeans convicted in Indian courts to the Australian penal colonies and Asian convicts to destinations within the wider Indian Ocean world. ${ }^{54}$ However, several hundred black convicts counted amongst the 167,000 prisoners shipped to Australia from Britain, the Caribbean, Mauritius, the Cape Colony and New Zealand. 55

As in French Guiana, the British on occasion substituted convicts for slaves, enabling colonial administrators to engage in the rhetoric of abolition while securing an alternative source of labour. When Stamford Raffles took control of Bencoolen in 1818 , one of his first acts was to abolish slavery. Almost immediately he replaced slaves with regular shipments of Bengal convicts. Indian convicts were subsequently used in Malacca and Singapore (which with Penang constituted the Straits Settlements), as well as Burma.

Following the abolition of slavery across much of the empire in 1834, the British wound back penal transportation in all areas other than the Asian colonies. The last convicts to depart Britain arrived in Gibraltar in 1870.56 However, the number of convicts sentenced to penal servitude in Britain's Asian colonies increased. The British had experimented with a penal colony in the Andaman Islands in 1793-1799, shipping 300 convicts until the settlement was devastated by disease and abandoned. ${ }^{57}$ The islands again became a destination for convicts following the 1857 Rebellion and received a further 80,000 convicts up to $1940 .{ }^{58}$

Table 3. Estimates of British Convict Transportation Flows, 1615-1940 


\begin{tabular}{|c|c|c|c|}
\hline Origin & Destination & Period & Est. Number \\
\hline \multirow[t]{2}{*}{ England and Wales } & Caribbean and & $1615-$ & 6,000 \\
\hline & American colonies & 1717 & \\
\hline Scottish prisoners & Caribbean and & $1648-$ & 2,000 \\
\hline of war & American colonies & 1656 & \\
\hline \multirow[t]{2}{*}{ Ireland } & Caribbean & $1652-$ & 5,000 \\
\hline & & 1659 & \\
\hline Monmouth Rebels & American colonies & 1685 & 800 \\
\hline \multirow[t]{2}{*}{ Jacobite Rebels } & American colonies & $1715-$ & 1,300 \\
\hline & & 1746 & \\
\hline \multirow[t]{2}{*}{ Britain and Ireland } & American colonies & $1718-$ & 48,000 \\
\hline & & 1774 & \\
\hline \multirow[t]{2}{*}{ Ireland } & American colonies & $1776-$ & 1,000 \\
\hline & & 1789 & \\
\hline \multirow[t]{2}{*}{ Britain and Ireland } & Military service & $1766-$ & 15,000 \\
\hline & & 1826 & \\
\hline \multirow[t]{2}{*}{ Britain and Ireland } & New South Wales & $1788-$ & 83,000 \\
\hline & & 1850 & \\
\hline \multirow[t]{2}{*}{ British colonies } & New South Wales & $1807-$ & 500 \\
\hline & & 1842 & \\
\hline \multirow[t]{2}{*}{ British colonies } & Van Diemen's & $1803-$ & 67,500 \\
\hline & Land & 1853 & \\
\hline \multirow[t]{2}{*}{ British colonies } & Van Diemen's & $1810-$ & 5,000 \\
\hline & Land & 1853 & \\
\hline Britain and Ireland & Port Phillip & $1846-$ & 3,000 \\
\hline
\end{tabular}


Britain and Ireland

Britain and Ireland

Britain and Ireland

British India

British India

Straits

Settlements**

British India

British India and

Ceylon

British India

Bombay Presidency

Aden

Mauritius

Tenasserim

Bengal Presidency

Andaman Islands

British India plus

Burma and
Andaman Islands

1858

80,000
1828

1862

$1841-$ 150

1850

1793

300

1796

20,000

1,000

500

1,500

5,000

1940 
Hyderabad

Total

$1615-$

376,250

1940

\footnotetext{
* Straits Settlements = Penang, Malacca and Singapore

** Straits Settlements plus Burma and Hong Kong
}

\section{Convict Transportation and Western Imperialism}

As mentioned earlier, over time there occurred a shift in the character of penal transportation, away from the assimilation of convicts into larger labour streams, and towards the establishment of discrete, isolated, penal colonies. Each convict flow was generated, sustained and ultimately abolished for combinations of economic, penal and social reasons, including those bound up with the use of labour for national or imperial expansive strategies. Over time the emphasis on extractive labour was maintained. Each was also deeply embedded in a larger repertoire of confinement concerned with the management and control of labour and social 'undesirables'. Penal transportation, thus, may be situated as part of a larger imperial history of labour, labour management and labour circulation although this remains largely unrecognised in the current historiography. ${ }^{59}$

In a highly influential claim, often cited since its publication in 1900, $\mathrm{H}$. J. Nieboer stated that when land is abundant and cheap, unfree labour becomes a necessity - and therefore there is a strong connection between unfreedom and the desire to expand into unsettled land (or what Nieboer called 'open resources'). ${ }^{60}$ Certainly, his assertion appears to hold true for penal transportation. There indeed existed a close association between the use of 
convict labour and colonies where free migrants could easily acquire land and hence escape waged labour. ${ }^{61}$ In practice, convicts often shifted between what Jan Lucassen has called the 'unfree' and 'independent' labour markets, combining forced work over which they had little control with other economic activities, including petty production. ${ }^{62}$ This was typical of convict labour in early New South Wales. ${ }^{63}$

Despite the potential of penal transportation to help explain that most Eurocentric global phenomenon - the rise of Europe — paradoxically it also offers a less Eurocentric way of understanding global history. The extent of intra-colonial transportation foregrounds not metropolitan flows of convicts outward, but the importance of the geographical 'circulation' of convicts. It opens out to view labour mobility as more than a straightforward migratory process with an easily defined geographical start and end point. ${ }^{64}$

In total, over 680,000 convicts were transported by the Western empires in the period 1415-1952 (substantially more if the French use of convicted labour to maintain the ranks of the BILA is included). If the Russian Empire were also incorporated, well over a million convicts were unwillingly co-opted into European colonisation projects. ${ }^{65}$ While this amounts to fewer than the number of slaves and indentured labourers used by European colonisers, transportation played a pioneering role in the colonisation process, through providing the necessary labour to establish colonial bridgeheads. Following the rise of the Atlantic slave trade, penal transportation became pivotal in supplying labour for fortification construction and defense. In the long-run it proved more durable than slavery, surviving the abolition era in all Western empires. While this enabled the continued movement of convicts from metropolitan areas to 
overseas penal settlements, it also provided colonial authorities with the means to relocate 'undesirable' subjects to the imperial margins. Both the British and the Spanish, for example, sentenced slaves to transportation and all Western empires established complex inter-colonial transportation flows. ${ }^{66}$

The demographic legacy of convict transportation varies. By and large, convicts did not make a substantial contribution to the growth of colonial populations as death rates were high and only small numbers of women were deported. There are many descendants who proclaim convict ancestry in the Andamans and Australia; but in other places convicts either merged into the wider population when they had children with non-convict women or were repatriated at the end of their sentence. ${ }^{67}$

Transportation was an instrument designed to achieve multiple objectives. It aimed to curb metropolitan crime rates, supply military and civilian labour to areas of colonial shortage, relocate those who threatened imperial security and pacify subject populations through the threat of enforced removal. ${ }^{68}$ Durable and flexible, it provided a tool that framed European colonisation. Convicts were present in the early sorties into North and West Africa and across the Atlantic. Four centuries later they were still there, defending Spanish colonial interests in the Rif, fighting in BILA units in Algeria, manning frontier settlements in Angola and surviving in the Andaman Islands until released by the occupying forces of Japan's Asian Empire in 1942.

\footnotetext{
${ }^{1}$ Farley Grubb, 'The Transatlantic Market for British Convict Labor', Journal of Economic History, Vol. 60, No. 1 (2000), p. 103.
} 
$\overline{{ }^{2} \text { Ruth Pike, 'Penal Servitude in the Spanish Empire: Presidio Labor in the Eighteenth }}$ Century', The Hispanic American Historical Review, Vol. 58, No. 1 (1978), p. 22; and Peter Spierenburg (ed.), The Emergence of Carceral Institutions, 1550-1900 (Rotterdam, 1984).

${ }^{3}$ J. D. Fage, 'Slaves and Society in Western Africa, c.1445-c.1700', The Journal of African History, Vol. 21, No. 3 (1980), pp. 307-308.

${ }^{4}$ Hamish Maxwell-Stewart, "'Like Poor Galley Slaves": Slavery and Convict Transportation', in Marie Suzette Fernandes Dias (ed.), Legacies of Slavery: Comparative Perspectives (Newcastle, 2007), pp. 48-61.

${ }^{5}$ Matthew J. Mancini, One Dies, Get Another: Convict Leasing in the American South, 1866-1928 (Columbia, 1996).

${ }^{6}$ Clare Anderson, 'After Emancipation: Empires and Imperial Formations', in Catherine Hall and Keith McClelland (eds.), Emancipation, Slave Ownership and the Remaking of the British Imperial World (Manchester, 2014).

${ }^{7}$ Colin Benbow, Boer Prisoners of War in Bermuda (Hamilton, 1962).

${ }^{8}$ Maxwell-Stewart, "“Like Poor Galley Slaves", pp. 48-61.

${ }^{9}$ Clare Anderson, 'Convicts and Coolies: Rethinking Indentured Labour in the Nineteenth Century', Slavery and Abolition, Vol. 30, No. 1 (2009), pp. 93-109. See also Anand A. Yang, 'Indian Convict Workers in Southeast Asia in the Late Eighteenth and Early Nineteenth Centuries', Journal of World History, Vol. 14, No. 2 (2003), pp. 3-4.

${ }^{10}$ James A. Armstrong, 'The Chinese exiles', in Nigel Worden (ed.), Cape Town. Between East and West. Social Identities in a Dutch Colonial Town (Auckland Park, 2012), p. 102; and Kerry Ward, Networks of Empire: Forced Migration in the Dutch East India Company (Cambridge, 2009). 
${ }^{11}$ Richard Evans, 'Germany’s Convict Exports', History Today, Vol. 47, No. 11 (1997), pp. 11-17.

${ }^{12}$ Gerald Bender, Angola Under the Portuguese: The Myth and the Reality (London, 1978), p. 60 .

${ }^{13}$ Christopher DeCorse, An Archaeology of El Mina (Washington, 2001), pp. 35-36.

${ }^{14}$ Timothy Coates, Convicts and Orphans: Forced and State-Sponsored Colonizers in the Portuguese Empire, 1550-1755 (Stanford, 2001); and C. R. Boxer, The

Portuguese Seaborne Empire, 1415-1825 (London, 1969), p. 313.

${ }^{15}$ Charles Boxer, The Golden Age of Brazil, 1695-1750 (Berkeley, 1964), pp. 140 and 301.

${ }^{16}$ Bender, Angola Under the Portuguese, pp. 87-88.

${ }^{17}$ Bender, Angola Under the Portuguese, p. 60.

${ }^{18}$ Joseph Miller, Way of Death: Merchant Capitalism and the Angolan Slave Trade 1730-1830 (Madison, 1988), pp. 250-251.

${ }^{19}$ Bender, Angola Under the Portuguese, p. 61.

${ }^{20}$ Boxer, The Portuguese Seaborne Empire, p. 90.

${ }^{21}$ Boxer, The Golden Age of Brazil, p. 301.

${ }^{22}$ Timothy Coates, 'Preliminary Considerations on European Forced Labor in Angola, 1880-1930: Individual Redemption and the "Effective Occupation" of the Colony', Portuguese Literary \& Cultural Studies 15/16: Remembering Angola (2010), 79-106; and Bender, Angola Under the Portuguese, pp. 74-93.

${ }^{23}$ Timothy Coates, Forced Labor in the Portuguese Empire, 1740-1932 (forthcoming).

${ }^{24}$ As cited in Daniel, J. Garr, 'A Rare and Desolate Land: Population and Race in Hispanic California', The Western Historical Quarterly, Vol. 6, No. 2 (1975), p. 137. 
${ }^{25}$ Johan Thorsten Sellin, Slavery and the Penal System (New York, 1976), p. 63.

${ }^{26}$ Judith A. Bense, 'Presidios of the North American Spanish Borderlands', Historical Archaeology, Vol. 38, No. 3 (2004), pp. 1-5.

${ }^{27}$ Fernand Braudel, The Mediterranean and the Mediterranean World in the Age of Phillip II, Vol. 2, Sian Reynolds (trans.) (Berkeley, 1995), p. 862.

${ }^{28}$ Ronald Wayne Childers, 'The Presidio System in Spanish Florida, 1565-1763', Historical Archaeology, Vol. 38, No. 3 (2004), pp. 24-32; Judith A. Bense, 'Santa María De Galve (1698-1719): A Frontier Garrison in Spanish West Florida', Historical Archaeology, Vol. 38, No. 3 (2004), pp. 47-64; and Steven, W. Hackel, 'Land, Labor, and Production: The Colonial Economy of Spanish and Mexican California', California History, Vol. 76, No. 2/3 (1997), pp. 111-146.

${ }^{29}$ Carlos Marichal and Matilde Souto Mantecón, 'Silver and Situados: New Spain and the Financing of the Spanish Empire in the Caribbean in the Eighteenth Century', The Hispanic American Historical Review, Vol. 74, No. 4 (1994), p. 609.

${ }^{30}$ Colin, M. MacLachlan, Criminal Justice in Eighteenth-Century Mexico: A Study of the Tribunal of Acordada (Berkeley, 1974), pp. 34 and 114.

${ }^{31}$ Ruth Pike, 'Penal Servitude in the Spanish Empire: Presidio Labor in the Eighteenth Century', The Hispanic American Historical Review, Vol. 58, No. 1 (1978), p. 22.

${ }^{32}$ Ruth Pike, Penal Servitude in Early Modern Spain (Madison, 1983), pp. 111-33.

${ }^{33}$ Manuela Marín, “"Hombre Al Moro”: Fugas Del Presidio De Melilla En El Siglo Xix (1846-1869', Hispania, Vol. LXX, No. 234 (2010), p. 49.

${ }^{34}$ See Glasgow Herald, 1 March 1886; The Deseret News, 20 May 1899; Ibrahim K. Sundiata, The Bight of Biafra and Fernando Po in the Era of Abolition, 1827-1930 (Madison, 1996), p. 54. 
${ }^{35}$ R. Cadman Etches, Patrick Wilson and Richard H. Dillon, 'A Plan for Convict Colonies in Canada', The Americas, Vol. 13, No. 2 (1956), p. 187.

${ }^{36}$ James D. Hardy Jr., 'The Transportation of Convicts to Colonial Louisiana', Louisiana History, Vol. 7, No. 3 (1966), pp. 707-720; and P. N. Moogk, 'Reluctant Exiles: Emigrants from France in Canada before 1760', The William and Mary Quarterly, Vol. 46, No. 3 (1989), pp. 498-499.

${ }^{37}$ Peter Redfield, Space in the Tropics: From Convicts to Rockets in French Guiana (Berkeley, 2000), pp. 56-63.

${ }^{38}$ Patricia O’Brien, The Promise of Punishment: Prisons in Nineteenth-Century France (Princeton, 1982), pp. 258-262; and Stephen Toth, Beyond Papillon: The French Overseas Penal Colonies, 1854-1952 (Nebraska, 2006).

${ }^{39}$ Colin Forster, France and Botany Bay: The Lure of a Penal Colony, (Melbourne, 1996), pp. 128-142; and Redfield, Space in the Tropics, p. 34.

${ }^{40}$ Miranda Spieler, Empire and Underworld: Captivity in French Guiana (Cambridge, 2012).

${ }^{41}$ Redfield, Space in the Tropics, pp. 66-69.

${ }^{42}$ Isabelle Merle, Expériences Coloniales: La Nouvelle-Calédonie, 1853-1920 (Belin, 1995); Alice Bullard, Exile to Paradise: Savagery and Civilization in Paris and the South Pacific (Stanford, 2000); O'Brien, The Promise of Punishment, p. 285.

${ }^{43}$ Hamish Maxwell-Stewart, 'Isles of the Dead: Convict Death Rates in Comparative Perspective', Historic Environment, Vol. 24, No. 3 (2012), pp. 26-34.

${ }^{44}$ O'Brien, The Promise of Punishment, pp. 274-275.

${ }^{45}$ Benjamin McRae Amoss, 'The Revolution of 1848 and Algeria', The French Review, Vol. 75, No. 4 (2002), pp. 744-754; and Marc Renneville, 'Les Bagnes 
Coloniaux: de l'Utopie au Risque du Non-lieu', http://criminocorpus.revues.org/173 [accessed 21 October 2012].

${ }^{46}$ Dominique Kalifa, Biribi: Les Bagnes coloniaux de l'Armée Française (Paris, 2009).

${ }^{47}$ Sean O'Callaghan, To Hell or Barbados: The Ethnic Cleansing of Ireland (Dingle, 2000).

${ }^{48}$ Carla Pestana, The English Atlantic in the Age of Revolution 1640-61 (Cambridge, 2004), pp. 183-189; David Dobson, Scottish Immigration to Colonial America, 16071785 (Athens, Georgia, 2004), pp. 33-36; and Margaret D. Sankey, Jacobite Prisoners of the 1715 Rebellion: Preventing and Punishing Insurrection in Early Hanovarian Britain (Aldershot, 2005), pp. 59-63.

${ }^{49}$ Hamish Maxwell-Stewart, 'Convict Transportation from Britain and Ireland, 16151870', History Compass, Vol. 8, No. 11 (2010), p. 1224; A. R. Ekirch, Bound for America: The Transportation of British Convicts to the Colonies, 1718-75 (Oxford, 1990), pp. 23 and 188; and James Kelly, 'Transportation from Ireland to North America, 1703-1789', in David Dickson and Cormac Ó Gráda (eds.), Refiguring Ireland (Dublin, 2003), pp. 112-135.

${ }^{50}$ Robert Reece, The Origins of Convict Transportation to New South Wales (Basingstoke, 2001).

${ }^{51}$ Emma Christopher and Hamish Maxwell-Stewart, 'Convict Transportation in Global Context, c. 1700-88', in Alison Bashford and Stuart McIntyre (eds.), Cambridge History of Australia, Vol. 1 (Cambridge, 2013), p.76; and Peter Burroughs, 'Crime and Punishment in the British Army, 1815-1870', The English Historical Review, Vol. 100, No. 396 (1985), p. 560. 
${ }^{52}$ Roger N. Buckley, The British Army in the West Indies: Society and the Military in the Revolutionary Age (Gainsville, 1998), pp. 100-106.

${ }^{53}$ British Parliamentary Papers, Sessional Papers printed by Order of the House of Lords, XVII (1840), pp. 18-20.

${ }^{54}$ Clare Anderson Subaltern Lives: Biographies of Colonialism in the Indian Ocean World, 1790-1920 (Cambridge, 2012), pp. 56-92.

${ }^{55}$ Cassandra Pybus, Black Founders: The Unknown Story of Australia's First Black Settlers (Sydney, 2006); Kristyn Harman, Aboriginal Convicts: Australian, Khoisan and Maori Exiles (Sydney, 2012); and Anderson, Subaltern Lives, pp. 56-92.

${ }^{56}$ Maxwell-Stewart, 'Convict Transportation', p. 5.

${ }^{57}$ Clare Anderson, The Indian Uprising of 1857-8: Prisons, Prisoners and Rebellion (London, 2007), pp. 127-176.

${ }^{58}$ British Library, Asia Pacific \& Africa Collections, V/10 Andaman \& Nicobar Annual Reports, 1872-1940. For other minor flows, see Christopher Munn, 'The Transportation of Chinese Convicts from Hong Kong', Journal of the Canadian Historical Association, Vol. 8, (1997), pp. 113-145; and The Strait Times, 27 August 1870. All other estimates based on Anderson, Subaltern Lives.

${ }^{59}$ For example Leo Lucassen and Jan Lucassen (eds.), Migration, Migration History, History (Bern, 2005); P. Manning, Migration in World History (London, 2005); 'Migration and World History', International Review of Social History, Vol. 52 (2007); 'Discussion: Global Migration', Journal of Global History, Vol. 6, No. 2 (2011). But see U. Bosma, 'European Colonial Soldiers in the nineteenth century: Their Role in White Global Migration and Patterns of Colonial Settlement', Journal of Global History, Vol. 4, No. 2 (2009), pp. 317-336.

${ }^{60}$ H. J. Nieboer, Slavery as an Industrial System (The Hague, 1900). 
${ }^{61}$ Stephen Nicholas, 'The Convict Labour Markets', in S. Nicholas (ed.) Convict Workers (Cambridge, 1988), pp. 11-126.

${ }^{62}$ See Jan Lucassen on these (and other) theoretical and empirical issues: 'Free and Unfree Labour Before the Twentieth Century: A Brief Overview', in Tom Brass and Marcel van der Linden (eds.), Free and Unfree Labour: The Debate Continues (New York, 1997), pp. 45-56.

${ }^{63}$ W. M. Robbins, 'Spatial Escape and the Hyde Park Convict Barracks', Journal of Australian Colonial History, Vol. 7 (2005), pp. 81-96; and Clare Anderson, 'Convicts and Coolies: Rethinking Indentured Labour in the Nineteenth Century', Slavery and Abolition, Vol. 30, No. 1 (2009), pp. 93-109.

${ }^{64}$ Prabhu Mohapatra, 'Eurocentrism, Forced Labour, and Global Migration: A Critical Assessment', International Review of Social History, Vol. 52 (2007), pp. 110-15. Cf. C. Markovits, J. Pouchepadass and S. Subrahmanyam (eds.), Society and Circulation (New Delhi, 2003).

${ }^{65}$ For Russian estimates and the only previous attempt to innumerate European transportation flows, see Stephen Nicholas and Peter Shergold, 'Transportation as Global Migration', in Nicholas, Convict Workers, pp. 28-42.

${ }^{66}$ Diana Paton, 'Punishment, Crime, and the Bodies of Slaves in Eighteenth-Century Jamaica', Journal of Social History, Vol. 34, No. 4 (2001), pp. 923-954; and Freeman's Journal and Daily Commercial Advertiser, 4 March 1843.

${ }^{67}$ Maxwell-Stewart, 'Isles of the Dead', p. 34.

${ }^{68}$ Hamish Maxwell-Stewart, Closing Hell's Gates: The Death of a Convict Station (Sydney, 2008), pp. 139-164. 
Further Reading

Anderson, Clare, Subaltern Lives: Biographies of Colonialism in the Indian Ocean World, 1790-1920 (Cambridge, 2012).

Bullard, Alice, Exile to Paradise: Savagery and Civilization in Paris and the South Pacific (Stanford, 2000).

Coates, Timothy, Convicts and Orphans: Forced and State-Sponsored Colonizers in the Portuguese Empire, 1550-1755 (Stanford, 2001).

Duffield, Ian and Bradley, James (eds.), Representing Convicts: New Perspectives on Convict Forced Labour Migration (Leicester, 1997).

Ekirch, A. R., Bound for America: The Transportation of British Convicts to the Colonies, 1718-75 (Oxford, 1990).

Kalifa, Dominique, Biribi: Les Bagnes Coloniaux de l'Armée Française (Paris, 2009).

Maxwell-Stewart, Hamish, Closing Hell's Gates: The Death of a Convict Station (Sydney, 2008).

Nicholas, Stephen (ed.), Convict Workers: Reinterpreting Australia's Past (Cambridge, 1988).

Pieris, Anoma, Hidden Hands and Divided Landscapes: A Penal History of Singapore's Plural Society (Honolulu, 2009).

Pike, Ruth, Penal Servitude in Early Modern Spain (Madison, 1983).

Redfield, Peter, Space in the Tropics: From Convicts to Rockets in French Guiana (Berkeley, 2000).

Sen, Satudra, Disciplining Punishment: Colonialism and Convict society in the Andaman Islands (Oxford, 2000). 
Shaw, A.G.L., Convicts and Colonies: A Study of Penal Transportation from Great Britain and Ireland to Australia and other Parts of the British Empire (London, 1966).

Toth, Stephen, Beyond Papillon: The French Overseas Penal Colonies, 1854-1952 (Nebraska, 2006).

Ward, Kerry, Networks of Empire: Forced Migration in the Dutch East India Company (Cambridge, 2009). 